\title{
Effects of Topping on the Selección Olor Tobacco Variety ${ }^{1}$
}

\section{L. Gonzälez Molina, A. Sierra Bracero, and E. G. Boneta García ${ }^{2}$}

\section{INTRODUCTION}

Topping filler-type tobacco in Puerto Rico is a regular practice among tobacco growers. Topping at different leaf-heights induces changes in the leaves. Leaves of topped plants are generally larger and thicker than those from untopped ones. The magnitude of the changes depends upon variety, planting distance, height of topping, fertilizing level, physiological maturity of the leaves, weather conditions, and other factors.

At the same time topping promotes sucker formation. Untopped plants probably produce a phytohormone in the growing buds that suppresses suckers. Once the bud is removed this suppressive action is eliminated. No changes in the leaves are obtained by topping if suckering does not follow. The practice of suckering is an additional expense to farmers mainly when topping is low. Farmers were accustomed up to recent years to low topping in order to increase yield and quality. The industry used to prefer large and heavier leaves, therefore, better prices were obtained for such tobacco. It should be pointed out that tobacco used in cigar manufacture was stripped by hand so it was cheaper to work with long, heavy leaves than with short ones.

Recently, a transformation has occurred in the eigar industry. The use of stripped tobacco has been reduced to about 7 percent. Most of the tobacco currently used is chopped. With this change leaf size has become of secondary importance. But many tobacco farmers still prefer low topping and, as a consequence, they are increasing costs of production and probably decreasing the yield.

At present the variety Selección Olor, developed at the Gurabo Experiment Substation, is preferred in most of the tobacco areas because of its high yields. This is a tall variety with about 46 to 48 leaves of acceptable size $(3)^{3}$, late-maturing, and of good curing and fermenting quality. As this variety is widespread throughout the Tobacco Region extensive experimental work has been undertaken concerning the factors that affect crop yield and quality. In the experiment herein reported the effects of

${ }^{1}$ Contribution from the Gurabo Substation.

${ }^{2}$ Assistant Plant Breeder, and Research Assistants in Agronomy, respectively, gricultural Experiment Station, University of Puerto Rico, Gurabo, P.R.

3 Italic numbers in parentheses refer to Literature Cited, p. 318. 
different topping heights on Selección Olor were studied in order to determine the response of this variety to topping.

\section{REVIEW OF THE LITERATURE}

Woltz (7) from the North Carolina Experiment Station, working with flue-cured tobacco, found that plots topped at an 18- to 24-leaf height, followed by complete suckering, produced the highest yields and value indices per acre, while those not topped gave the lowest yields and value indices. Nichols and McMurtrey (4) found that topping moderately high and pulling suckers could increase the tobacco crop value as much as 25 percent. Carr and Neas (1) found a highly significant difference when high topping was practiced on flue-cured tobacco as compared with low topping and no topping. The U.S. Department of Agriculture (5) suggests topping at not more than 16 leaves, if favorable weather conditions prevail, and at 10 to 12 leaves under adverse conditions for cigar tobacco in Pennsylvania. At the Agricultural Experiment Station of Virginia (6) it was found that topped and suckered tobacco produced 231 more pounds of tobacco per acre than untopped and unsuckered tobacco.

\section{MATERIALS AND METHODS}

Two consecutive experiments were conducted during 1960 and 1961, at the Gurabo Substation. The experimental area for the first one was in an alluvial soil, while the second was grown in a Múcara soil. A complete randomized-block design replicated five times was used in both experiments. The four treatments under comparison were as follows: 1 , Topping at 20 leaves; 2 , topping at 26 leaves; 3 , topping at 32 leaves; 4 , untopped plants.

Each experimental plot consisted of 5 rows with 12 plants per row, that is, 60 plants per plot. Tobaceo was planted at a distance of $31 / 2$ feet between rows and 18 inches between plants. Selección Olor, a commercial variety developed recently at the Gurabo Substation, was used. Seedbeds were made in clay pots filled with a soil mixture of 1 part of loam to 1 part of filter-press cake. The soil was sterilized with methyl bromide at the rate of 2 pounds per 100 square feet.

Three to four weeks after sowing seedlings were transferred to vita bands on flats with sterilized soil. Three weeks later they were transplanted to the experimental field. A 6-8-10 fertilizer was applied in split portions in the holes at time of planting at a rate of 15 hundredweights per acre. Cultural practices and insect control followed standard Station recommendations.

In topping, the growing buds were removed by hand as soon as the plants reached the desired height. The first pair of basal leaves was not considered for any of the treatments. Suckering was done at least weekly. When harvesttime began tobacco leaves were primed every week and cured 
in a conventional curing shed. Cured leaves were classified according to the USDA standards. Weight of cured tobacco and crop value per treatment were recorded and used as criteria for treatment evaluation.

TABLE 1.-Weight in pounds of cured tobacco and cash value of the crop per treatment in 2 experiments performed at Gurabo, P.R., during the years 1960 and 1961

\begin{tabular}{c|c|c} 
Treatment & $\begin{array}{c}\text { Mean weight per cuerda of } \\
\text { cured tobacco }\end{array}$ & $\begin{array}{c}\text { Mean cash value per cuerda } \\
\text { of classified tobacco }\end{array}$ \\
\hline
\end{tabular}

1960 experiment

Topped at 20 leaves

Topped at 26 leaves

Topped at 32 leaves

Not topped

\begin{tabular}{c|c} 
Pounds & Dollars \\
1,258 & 402 \\
1,468 & 484 \\
1,581 & 504 \\
1,515 & 480
\end{tabular}

1961 experiment

Topped at 20 leaves

Topped at 26 leaves

Topped at 32 leaves

Not topped

1,352
1,490
1,638
1,695

376

409

464

440

TABLE 2.-Summary of the anlayses of variance of cured tobacco per treatment for 2 experiments performed at Gurabo, P.R., during 1960 and 1961

\begin{tabular}{|c|c|c|c|c|c|c|c|c|c|}
\hline \multirow{3}{*}{ Source of error } & \multirow{3}{*}{$\begin{array}{l}\text { Degree of } \\
\text { freedom }\end{array}$} & \multicolumn{2}{|c|}{1960} & \multicolumn{2}{|c|}{1961} & \multicolumn{4}{|c|}{ F values } \\
\hline & & \multirow{2}{*}{$\begin{array}{l}\text { Sum of } \\
\text { squares }\end{array}$} & \multirow{2}{*}{$\begin{array}{l}\text { Mean of } \\
\text { squares }\end{array}$} & \multirow{2}{*}{$\begin{array}{l}\text { Sum of } \\
\text { squares }\end{array}$} & \multirow{2}{*}{$\begin{array}{l}\text { Mean of } \\
\text { squares }\end{array}$} & \multicolumn{2}{|c|}{ Experimental } & \multirow{2}{*}{$\begin{array}{c}5 \\
\text { percent }\end{array}$} & \multirow{2}{*}{$\begin{array}{c}1 \\
\text { percent }\end{array}$} \\
\hline & & & & & & 1960 & 1961 & & \\
\hline Total & 19 & 80.029 & & 75.023 & & & & & \\
\hline Block & 4 & 19.904 & & 12.047 & & & & & \\
\hline Treatment & 3 & 24.374 & 8.124 & 20.007 & 6.669 & 2.131 & 1.86 & 3.49 & 5.95 \\
\hline Error & 12 & 45.751 & 3.812 & 42.969 & 3.581 & & & & \\
\hline
\end{tabular}

\section{RESULTS AND DISCUSSION}

Table 1 gives the mean yields of cured tobacco and crop values per cuerda $a^{4}$ of both experiments, 1960 and 1961. Although some differences in yield and crop value are observed among treatments, the analyses of variance (see tables 2 and 3 ) indicated that such differences might be attributable to random effects rather than to treatment differences. No significant

\footnotetext{
${ }^{4}$ A cuerda is equivalent to 0.97 acre.
} 
differences in yield or crop value were observed at different topping heights. This indicates that the height at which the variety Seleccion Olor is topped does not influence either yield or crop values. Results obtained in these experiments are not in agreement with those obtained in the experiments previously cited where significant differences were recorded between topped and untopped or low-topped and high-topped tobacco.

It is well-known that topping interrupts plant growth to some extent and, of course, delays leaf maturity. Although no additional tissues are produced in the leaves, cells increase their size and, consequently, leaf size, and thickness increase. The magnitude of these changes depends upon several factors, as already mentioned. Since Selección Olor is a tall variety producing some 46 to 48 leaves, it is not favored by low topping. 'The increase in leaf size and thickness could not compensate for the weight of the

TABLE 3.-Summary of the analyses of variance of the cash value of the crop of cured tobacco per treatment for 2 experiments performed at Gurabo, P.R., during 1960 and 1961

\begin{tabular}{|c|c|c|c|c|c|c|c|c|c|}
\hline \multirow{3}{*}{ Source of error } & \multirow{3}{*}{$\begin{array}{l}\text { Degree of } \\
\text { freedom }\end{array}$} & \multicolumn{2}{|c|}{1960} & \multicolumn{2}{|c|}{1961} & \multicolumn{4}{|c|}{ F values } \\
\hline & & \multirow{2}{*}{$\begin{array}{l}\text { Sum of } \\
\text { squares }\end{array}$} & \multirow{2}{*}{$\begin{array}{l}\text { Mean of } \\
\text { squares }\end{array}$} & \multirow{2}{*}{$\begin{array}{l}\text { Sum of } \\
\text { squares }\end{array}$} & \multirow{2}{*}{$\begin{array}{l}\text { Mean of } \\
\text { squares }\end{array}$} & \multicolumn{2}{|c|}{ Experimental } & \multirow{2}{*}{$\begin{array}{c}5 \\
\text { percent }\end{array}$} & \multirow{2}{*}{$\begin{array}{c}1 \\
\text { percent }\end{array}$} \\
\hline & & & & & & 1960 & 1961 & & \\
\hline Total & 19 & 8.182 & & 6.835 & & & & & \\
\hline Block & 4 & 3.240 & & 1.271 & & & & & \\
\hline Treatment & 3 & 1.521 & 0.507 & 2.061 & 0.687 & 1.78 & 2.35 & 3.49 & 5.95 \\
\hline Error & 12 & 3.421 & .285 & 3.503 & .292 & & & & \\
\hline
\end{tabular}

leaves discarded by low topping. Probably low topping could be better for short varieties rather than for tall ones. On the other hand, topping at 32 leaves did not produce the expected desirable effects on the leaves.

Although the upper leaves of topped plants seem to be larger than those from untopped treatments, differences were not so well marked as to cause significant differences between treatments. It might be well to point out that both experiments were conducted during a dry season, as shown in the following tabulation giving rainfall data at Gurabo during the two experiments:

Period

Jan. 5-31, 1960

Feb. 1-28, 1960

Mar. 1-20, 1960

Jan. 5-31, 1961

Feb. 1-28, 1961

Mar. 1-20, 1961
Incies

0.50

2.45

.49

.73

2.21

.33 
During a period of drought (6), high topping might have an adverse effect since the excess number of leaves will not fully develop.

Further research will be required to determine how climatic conditions and other factors interact with topping height. As topping induces sucker growth and, of course, with low topping, suckering practices will be more necessary, it will increase costs of production considerably. In view of all these facts it might be advisable to practice high topping or keep the plantation untopped rather to use than low or intermediate topping. It is obvious that topping improves leaf quality, but farmers do not currently obtain any premium price, since tobacco grading is done mainly on a basis of the physical rather than the chemical properties of the leaves. Therefore it will be more economical for farmers to keep their fields of Selección Olor untopped or, if preferred, to practice high topping.

\section{SUMMARY}

The data herein reported on two experiments carried on at Gurabo, P.R., during 1960 and 1961 show that there are no significant differences in yields when topping Selección Olor, a filler-type tobacco, at various heights. Thus since suckering in low and intermediate topping will increase the cost of production without compensation either in yield or in cash value of the crop, high topping or no topping at all seems advisable. As the development of leaves after topping depends upon various factors such as variety, weather conditions, fertilizing levels, planting distance, and leaf maturity, additional research is necessary to determine how these factors interact with topping effects. It is obvious that topping increases leaf size and thickness, but the changes recorded in our experiments were not sufficient to compensate for the leaves lost with topping.

Although the chemical properties determining leaf quality are improved by topping, farmers do not receive any benefit, since tobacco grading is mainly done on a basis of physical properties of leaves rather than on an objective chemical basis. Low or intermediate topping is not advisable when growing Seleccion Olor, although it might be favorable for short or intermediate varieties.

\section{RESUMEN}

En dos experimentos hechos en la Subestación Experimental Agrícola de Gurabo con el fin de evaluar las diferencias en rendimiento e ingreso de la cosecha, mediante el cape de las plantas de tabaco de la variedad Selección Olor, no se encontró diferencia alguna entre los distintos tratamientos.

Tal parece que cuando el cape es bajo, el beneficio que se deriva de esta práctica no es suficiente para compensar el gran número de hojas que se pierden durante la operación.

Debido a que la variedad Selección Olor es de madurez tardía y produce 
un gran número de hojas, no se adapta bien a los tipos de cape bajos o intermedios.

Cuando se capa la planta de tabaco se provoca la producción de tallos secundarios y renuevos, los cuales hay que eliminar cada 6 u 8 días.

Esta es labor que acarrea gastos adicionales que aumentan el costo producción, sin que el rendimiento adicional compense dichos gastos.

A pesar de que el cape mejora el tamaño y la calidad del tabaco, ésto no significa beneficio alguno para el agricultor, ya que los lotes de tabaco se clasifican principalmente a base de los caracteres físicos de las hojas y no de las propiedades químicas de las mismas.

Debido a que varios factores, tales como: condiciones climáticas, niveles de fertilidad, madurez fisiólogica de las hojas, clase de variedad, densidad de siembra, etc., pueden afectar la eficiencia de las diferentes alturas de cape, es que se recomienda que se continúen las investigaciones encaminadas a determinar los efectos de esas influencias sobre la eficacia del cape.

Hasta tanto no se obtenga evidencia que demuestre lo contrario a esta aseveración, se recomienda que los agricultores que siembran la variedad Selección Olor practiquen un cape alto, o mantengan las plantaciones sin capar, pues esto es lo más económico.

\section{LITERATURE CITED}

1. Carr, M. J., and Neas, I., Topping and Spacing Flue-Cured Tobacco, Georgia Coastal Plain Exp. Sta., Cir. 20, 1-16, 1951.

2. Garner, W. W., The Production of Tobacco, The Blakiston Co., Toronto, Canada, 140-6, 1946.

3. González-Molina, C. L., Acosta-Matienzo, A., and Boneta-García, J. G., Evaluation of four commercial varieties of tobacco, J. Agr. Univ. P.R., 46 (1) 43-7, 1962.

4. Mathews, E. M., Topping and Suckering Tobacco Produces more Leaf, Research in Farming, Annual Rept. of the Va. Agr. Exp. Sta., Blacksburg, Va., 20, 104647.

5. Nichols, B. C., and McMurtrey, J. E., Jr., It Pays to Top and Sucker Burley, Tenn., Farm and Home Science, Prog. Rept. No. 18, Apr.-June 7, 1956.

6. Street, O. E., Producing Cigar Tobacco in Pennsylvania, Farmers Bul. 2001, USDA, pp. 12-3, 1948.

7. Woltz, W. G., Some Effects of Topping and Suckering Flue-Cured Tobacco, Agr. Exp. Sta., N.C. Tech. Bul. 106, 1-24, 1955. 